\title{
Management of Arteriovenous Malformations by Stereotactic Radiosurgery: A Single Center Experience
}

\author{
Ferhat DINCOGLAN ${ }^{1}$, Omer SAGER ${ }^{1}$, Hakan GAMSIZ ${ }^{1}$, Selcuk DEMIRAL ${ }^{1}$, Bora UYSAL ${ }^{1}$, \\ Serdar SURENKOK ${ }^{1}$, Sait SIRIN², Kaan OYSUL ${ }^{1}$, Murat BEYZADEOGLU ${ }^{1}$ \\ ${ }^{1}$ Gulhane Military Medical Academy, Department of Radiation Oncology \\ ${ }^{2}$ Gulhane Military Medical Academy, Department of Neurosurgery, Ankara, TURKEY
}

\begin{abstract}
The aim of this monoinstitutional study is to evaluate the efficiency of stereotactic radiosurgery (SRS) in the management of arteriovenous malformations (AVM). Between June 1998 and July 2011, 51 patients with AVM were treated with linear accelerator-based SRS at our department. All patients were preevaluated for AVM size, location, neurological status, previous history of hemorrhage and Spetzler-Martin grading. Treated patients then underwent follow-up to evaluate obliteration and clinical status. Median followup time was 32 months (range; 20-93 months). Spetzler-Martin grade I-II and AVM sizes below $3 \mathrm{~cm}$ were associated with increased obliteration rate $(p=0.01)$. The annual hemorrhage risk was $1.9 \%$. No patients experienced deterioration of neurological status at follow-up. LINAC-based SRS is a safe and effective treatment modality in the management of cerebral AVMs. SRS comprises an effective alternative to surgery for the treatment of particularly small AVMs inaccessible with surgery.

Keywords: Arteriovenous malformation, Stereotactic radiosurgery, Spetzler-Martin grading, SRS, Hemorrhage
\end{abstract}

\section{ÖZET}

\section{Arteriovenöz malformasyonların Manajmanında Stereotaktik Radyocerrahi: Tek Menkez Deneyimi}

Bu tek merkezli çalışmanın amacı stereotaktik radyocerrahinin (SRS) arteryovenöz malformasyon (AVM) manajmanındaki etkinliğinin değerlendirilmesidir. Kliniğimizde Haziran 1998 ile Temmuz 2011 tarihleri arasında arteryovenöz malformasyonlu 51 hasta Linak tabanlı stereotaktik radyocerrahi ile tedavi edilmiştir. Tedavi öncesinde tüm hastalar AVM boyutu, lokalizasyonu, nörolojik durum, önceden kanama öyküsü ve Spetzler-Martin derecelendirilmesi açısından değerlendirilmiştir. Tedavi sonrasında hastalar obliterasyon durumu ve klinik durum değerlendirmesi için takip edilmiştir. Medyan takip süresi 32 ay (sınılar; 20-93 ay) idi. Spetzler-Martin derece I-II ve AVM boyutunun 3 cm'den küçük olması artmış obliterasyon oranı ile ilişkiliydi ( $p=0.01$ ). YIllık kanama oranı \%1.9 idi. Takip süresinde hiçbir hastada nörolojik durumda kötüleşme gözlenmedi. LINAC tabanlı stereotaktik radyocerrahi serebral AVM manajmanında güvenli ve efektif bir tedavi modalitesidir. Stereotaktik radyocerrahi özellikle cerrahi ile ulaşlamayan küçük AVM'lerin tedavisi için cerrahiye efektif bir alternatif oluşturmaktadır.

Anahtar Kelimeler: Arteryovenöz malformasyon, Stereotaktik radyocerrahi, Spetzler-Martin derecelendirmesi, SRS, Hemoraji 


\section{INTRODUCTION}

Arteriovenous malformations of brain are congenital malformations of the arteriovenous system which are composed of abnormal connections between veins and arteries with irregular vessel walls. Estimated annual incidence is $1 / 100.000^{1}$ and lifetime risk of hemorrhage for AVMs is $40 \%$, annual hemorrhage rate is $2 \%-4 \% .^{2-5}$

Patients are usually asymptomatic but may present with intracranial hemorrhage, headache and seizures. The Spetzler-Martin grading system is widely used to estimate the pretreatment risks and predict the outcome of patients with intracranial AVMs. ${ }^{6}$ Major complications of AVM are hemorrhage due to the fragile structure of vessel walls and hemorrhage-related complications such as seizures, headaches and neurologic deficits. AVMs may be treated with various modalities including surgery, radiosurgery and embolisation. The primary goal of treatment is preventing hemorrhage. Radiosurgery is a widely-accepted treatment modality for intracranial AVMs and its efficiency in decreasing the hemorrhage risk has been demonstrated previously. Surgical resection is usually not suitable for deepseated AVMs or those located in eloquent areas owing to the risk of damage to surrounding brain parenchyma; SRS is a viable therapeutic option for treating these lesions. In the early studies of Steiner about AVM radiosurgery ${ }^{8,9}$ it has been reported that high doses of radiation delivered to the entire nidus of malformation initiates a thromboobliterative process leading to the occlusion of pathologic vessels and this finding encouraged the use of SRS for the treatment of AVMs. ${ }^{10}$

AVMs should be managed with a multidisciplinary approach including neurosurgery, neuroradiology, interventional radiology and radiation oncology. Complication risk is present for all therapeutic options, namely surgery, embolisation and SRS. ${ }^{11-13}$ Izawa et al. ${ }^{14}$ defined long-term complications after Gamma Knife radiosurgery as hemorrhage, cyst formation and increase in seizure frequency. Complications are associated with the localization of AVMs. In the risk modelling study by Flickinger et al. ${ }^{15}$, postradiosurgery injury expression (SPIE) score was highest for AVMs located in medullar, thalamic, intraventricular, pons/midbrain, corpus callosum regions whereas the frontal lobe was suggested to be the least risky localization.
In this study, we evaluated the efficiency of SRS for intracranial arteriovenous malformations and report our experience.

\section{PATIENTS AND METHODS}

Between June 1998 and July 2011, 51 patients with AVM were treated using SRS at our department. All patients were evaluated for AVM size, location, neurological status, previous history of hemorrhage and Spetzler-Martin grading. Informed consent was required for inclusion into the study. All patients in the study were delivered high- precision SRS using linear accelerator with 6-MV photons. For the first 10 years, SRS planning was done with XKnife-3 (Radionics, Boston, MA, USA) and treatment was delivered by cone based SRS system (SL-25 (Elekta, UK). Radiosurgery planning system was then replaced with $\mathrm{ERGO}^{++}(\mathrm{CMS}$, Elekta, UK) allowing Volumetric Modulated Arc Radiosurgery, whereas treatments were given by Synergy (Elekta, UK) with $3 \mathrm{~mm}$ thickness head-on micro-MLC (micro multileaf collimator). On the day of treatment, a stereotactic frame (Leksell frame or 3D-Line frame, Elekta, UK) was affixed with 4 pins to the patient's skull under local anesthesia, and a planning CT scan usually fused with a prior MRI (T1-weighted contrast enhanced images with a slice thickness of $1 \mathrm{~mm}$ acquired 1-3 days before SRS) was used for treatment planning. In the planning; either a single 360-degree 18 arcs, double 360-degree 36 arcs, five 180-degree 45 arcs (crown) were selected to spare the critical structures around the target location. Target volume and critical structures were defined manually by both the treating radiation oncologist and neurosurgeon. Nidus was defined as the target and brainstem, motor strip, optic nerves, chiasm, eyes, and lens were defined as critical structures (SimMD, GE, UK). Windows and levels of the treatment planning CT were adjusted to improve visualization of the target and critical structures. Coronal and sagittal images were used in addition to axial images to improve target and organ-atrisk (OAR) delineation accuracy. AMOA (Arc Modulation Optimization Algorithm) was used to improve target coverage while sparing critical structures.

Median marginal dose was 18 Gy (range; 12-20 Gy). Treatment was prescribed to the $84 \%-96 \%$ isodose line (median 90\%) encompassing the tar- 

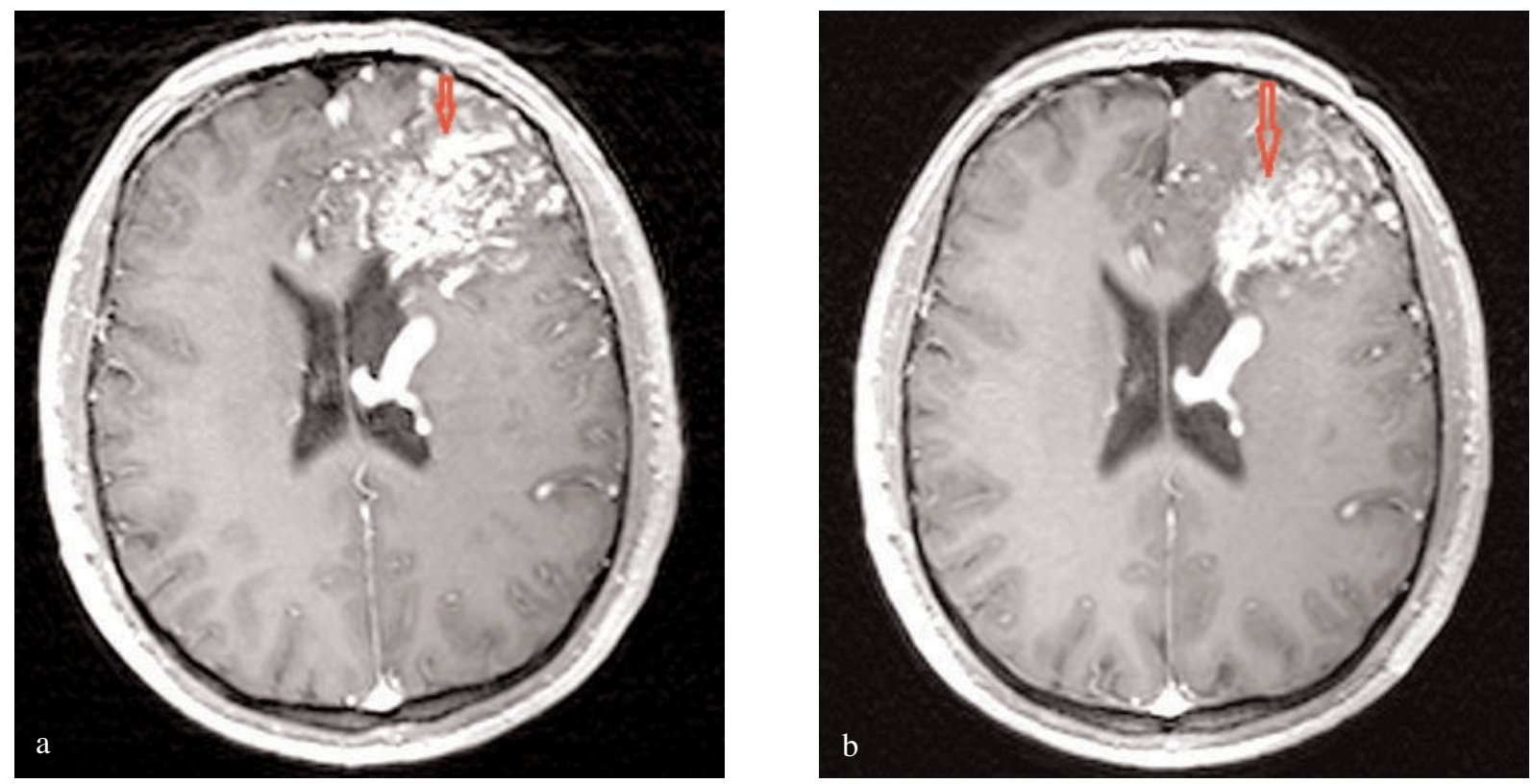

Figure 1a, b. Pre-SRS (1a) and 3 months after the first SRS session (1b) axial MRI of a patient allocated to undergo prospectively staged treatment in 3 sessions

get. Isocenters of all patients were checked by $\mathrm{kV}$ CBCT (kilovoltage Cone Beam CT) and setup verifications were done by XVI (X-ray Volumetric Imaging, Elekta, UK) system. 8 mg intravenous dexamethasone with $\mathrm{H} 2$-antihistamines was used immediately after SRS.

In 3 patients with an AVM volume $>15 \mathrm{cc}$, staged radiosurgery was performed by segmenting the large AVM volume into small treatment volumes defined with reference points such as major vessels, ventricles, and bony anatomy. The defined segments of the AVM was treated in multiple sessions. For these 3 patients, 1 patient was treated in 3 sessions while the remainders were treated in 2 sessions with an interval of 6 to 8 months between each session. Figure 1a and $\mathrm{b}$ show the pre-SRS and 3 months after the first SRS session axial MRI of a patient allocated to undergo prospectively staged treatment in 3 sessions.

After the completion of treatment, follow-up visits were scheduled for every patient routinely at 3month intervals for the first year, at 6-month intervals for the second year, and annually thereafter including clinical examination with neurological evaluation and neuroimaging with contrast-enhanced MRI. Angiography after SRS was scheduled when nidus was not detected on follow-up MRI.
Median follow-up time was 32 months (range;2093 months). Patients were requested to inform the treating physician about any unexpected neurological worsening regardless of the follow-up schedule.

Statistical Package for the Social Sciences, version 15.0 (SPSS, Inc., Chicago, IL) software and ChiSquare test was used for analysis and the level of significance was set at $\mathrm{p}<0.05$.

\section{RESULTS}

51 patients (28 male (55\%), 23 female (45\%)) with AVM were treated using SRS between June 1998 and July 2011. Median age was 32 years (range; 1358 years). AVM locations included temporal lobes in 16 patients $(31.4 \%)$, parietal lobes in 14 patients (27.4\%), frontal lobes in 11 patients $(21.5 \%)$, occipital lobes in 5 patients $(9.8 \%)$, cerebellar in 2 patients (4\%), thalamus and basal ganglia in 3 patients $(5.9 \%)$. The presenting sign was seizures in $18 \mathrm{pa}-$ tients (35.3\%), hemorrhage in 17 patients (33.3\%), headache in 15 patients $(29.4 \%)$ and neurological deficits (limb weakness) in 1 patients (2\%). Patient characteristics are shown on Table 1.

SRS was the first therapeutic approach in 42 patients (82.3\%). 7 patients (13.7\%) underwent embolisation before SRS; 4 patients underwent only one 


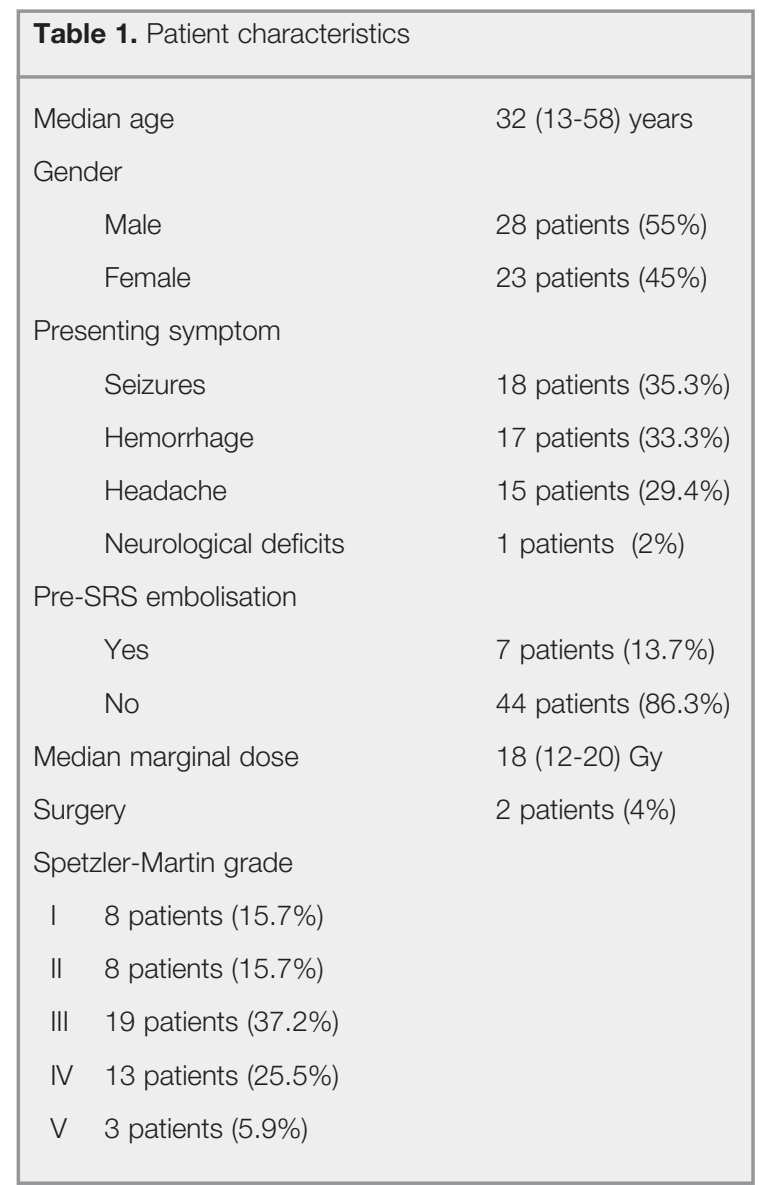

embolisation procedure while 3 patients underwent 2 embolisation procedures. All 7 patients treated with prior embolisation had residual AVM before SRS. 2 patients (4\%) had undergone previous surgery. Spetzler-Martin AVM classification was grade I in 8 patients $(15.7 \%$ ), grade II in 8 patients $(15.7 \%)$, grade III in 19 patients (37.2\%), grade IV in 13 patients $(25.5 \%)$ and grade $\mathrm{V}$ in 3 patients (5.9\%). Regarding the maximum diameter of the AVM, patients were classified into 3 groups: $\leq 20$ $\mathrm{mm}$ in 5 patients $(9.8 \%),>20 \mathrm{~mm}-\leq 30 \mathrm{~mm}$ in 37 patients $(72.5 \%)$ patients and $>30 \mathrm{~mm}$ in 9 patients $(17.7 \%)$. The median duration of symptoms was 10.2 months (range; 2-18 months).

Median maximum diameter of preSRS AVM was $23 \mathrm{~mm}$ (range; 8-52 mm). Median nidus volume was $3.7 \mathrm{cc}$ (range; $0.3-29.2 \mathrm{cc}$ ). Median marginal dose was 18 Gy (range; 14-20 Gy). Treatment was prescribed to the $84 \%-96 \%$ isodose line (median $90 \%)$. Median optic, brainstem and motor strip doses were 3.7 Gy (0.4-10 Gy) Gy and 4 Gy (0.2-10 Gy), 5.6 Gy (0.2-16 Gy) respectively.

Median follow-up time was 32 months (range; 2093 months). Angiography after SRS was scheduled when nidus was not detected on follow-up MRI. Improvement in neurological symptoms was observed in 26 patients $(51 \%)$; of these 26 patients 13 (25.5\%) had seizures, 12 (23.5\%) had headaches and $1(2 \%)$ had left sided limb weakness. Of the 17 patients with hemorrhage, 1 patient had hemorrhage after 5 months from the date of SRS. 37 patients $(72.5 \%)$ out of 51 patients completed 3-year follow up and angiograms for these patients demonstrated complete obliteration in 27 patients $(73 \%),>80 \%$ obliteration in 7 patients $(18.9 \%)$ and $<80 \%$ obliteration in 3 patients $(8.1 \%)$. Complete obliteration was correlated with Spetzler Martin grade I and II $(\mathrm{p}=0.014)$. Of the 37 patients who completed 3-year follow-up, 8 patients (15.7\%) were Spetzler Martin Grade I, 7 patients (13.7\%) were Spetzler Martin grade II, 13 patients $(25.5 \%)$ were grade III, and 9 patients (17.6\%) were grade IV. Complete obliteration was observed in 8 out of the 8 patients $(100 \%)$ with Spetzler Martin grade I AVMs, 6 out of the 7 patients $(85.7 \%)$ with Spetzler Martin grade II AVMs, 9 out of the 13 patients (69.2\%) with Spetzler Martin grade III AVMs, and 4 out of the 9 patients (44.4\%) with Spetzler Martin grade IV AVMs. We also found AVM size to be associated with complete obliteration $(\mathrm{p}=0.02)$. Of the 37 pati-

Table 2. AVM characteristics in patients with complete obliteration

\begin{tabular}{|c|c|c|c|c|c|c|c|}
\hline & \multirow[b]{2}{*}{$\leq 20$} & \multicolumn{2}{|c|}{ AVM size $(\mathrm{mm})$} & \multicolumn{4}{|c|}{ Spetzler Martin Grade } \\
\hline & & $20-30$ & $>30$ & Grade I & Grade II & Grade III & Grade IV \\
\hline Complete & $5 / 5$ & $20 / 26$ & $2 / 6$ & $8 / 8$ & $6 / 7$ & $9 / 13$ & $4 / 9$ \\
\hline Obliteration Rate & (100\%) & (76.9\%) & (33.3\%) & $(100 \%)$ & (85.7\%) & (69.2\%) & (44.4\%) \\
\hline
\end{tabular}


ents who completed 3-year follow-up, 5 patients had AVM sizes of $\leq 20 \mathrm{~mm}, 26$ patients had AVM sizes between $20-30 \mathrm{~mm}$, and 6 patients had AVM sizes $>30 \mathrm{~mm}$. Complete obliteration was observed in 5 out of the 5 patients (100\%) with AVM sizes $\leq$ $20 \mathrm{~mm}, 20$ out of the 26 patients $(76.9 \%)$ with AVM sizes between $20-30 \mathrm{~mm}$, and 2 out of the 6 patients $(33.3 \%)$ with AVM sizes $>30 \mathrm{~mm}$. Spetzler-Martin grade I-II and AVM sizes below $3 \mathrm{~cm}$ were associated with increased obliteration rates $(\mathrm{p}=0.01)$. Table 2 shows the AVM characteristics in patients with complete obliteration.

\section{DISCUSSION}

SRS is an effective treatment modality in the management of cerebral AVMs. Unlike surgery and embolization, the radiosurgical effect needs months or years to settle. In AVM radiosurgery, high dose radiation delivered in a single session causes endothelial cell injury and intimal layer thickening occurs through myofibroblast activation. Late changes include cellular degeneration, hyaline transformation, fragmentation of elastic laminae and vessel-wall mineralization. Progressive stenosis, luminal closure and obliteration of AVM nidus occurs in response to high dose radiation. The pathologic vessels forming the nidus are thought to be more radiosensitive than normal vessels..$^{15}$

Complete obliteration rates after SRS in the literature vary depending predominantly on AVM size and delivered dose. ${ }^{3}$ In the study by Friedman et al. ${ }^{5}$, in $48(56 \%)$ patients out of 85 patients with cerebral AVMs, complete obliteration was seen in angiography after a median interval of 23 months (range; 12-50 months). In the study of Schlienger et al. ${ }^{13}$, overall obliteration rate was $64 \%$ (108/169 patients) and median AVM size was $22 \mathrm{~mm}$ (range; 8$51 \mathrm{~mm}$ ) with a median peripheral dose of $25 \mathrm{~Gy}$ (range; 15-28Gy). Engenhart et al..$^{16}$ reported in their study that the degree of obliteration was associated with dose; complete obliteration rate to be $0 \%$ in 13 patients with doses $\leq 14 \mathrm{~Gy}, 50 \%$ for the 15 16 Gy group, and $80 \%$ for patients with doses $\geq 20$ Gy in their study.

Obliteration rate was shown to decrease with increasing AVM size. ${ }^{5,16}$ In the study of Friedman et al. ${ }^{5}$, complete obliteration was $81 \%$ for $1-4 \mathrm{cc}, 89 \%$ for $4-10 \mathrm{cc}$, and $69 \%$ for $>10 \mathrm{cc}$. Miyawaki et al.17 fo- und obliteration rates of $67 \%$ for $<4 \mathrm{cc}, 58 \%$ for 4 $13.9 \mathrm{cc}$, and $23 \%$ for $\geq 14 \mathrm{cc}$; higher minimal doses were significantly associated with AVM obliteration. In our study we observed complete obliteration in 27 out of the 51 patients $(52.9 \%)$ at 3 years. We found Spetzler-Martin grade I-II and $<3 \mathrm{~cm}$ AVM size to be associated with increased obliteration rates in our study $(\mathrm{p}=0.01)$.

The rupture risk of AVM is still present after SRS untill complete obliteration occurs. In the time interval between SRS and complete obliteration, the risk of rupture was suggested to be lower ${ }^{18}$, unchanged $^{19}$ or even higher ${ }^{20}$.Vessel wall fibrosis without complete obliteration might have a protective effect against hemorrhage. Intracranial hemorrhage rate after SRS was reported to be $2.1 \%$ annually until total obliteration..$^{21}$ In our study, annual hemorrhage rate was $1.9 \%$ after radiosurgery for the first year. Acute morbidity rate after SRS was reported to be approximately 5\% and radiosurgery was reported to have a potential to trigger seizures. ${ }^{5,22}$ We haven't observed an increase in the frequency of seizures in the acute period after SRS.

Complete obliteration rate is lower for larger AVMs $(\geq 15 \mathrm{cc})$ and the interval between SRS and complete obliteration is longer in patients with large AVMs. In the study by Miyawaki et al. ${ }^{15}$, after LINAC-bases SRS, complete obliteration rate was $23 \%$ for AVMs > $14 \mathrm{cc}$ and only 1 patient out of the total 73 patients was treated with prospective staged treatment. No complete obliteration was observed in patients treated with a dose $<14 \mathrm{~Gy}$ in their study. In the study by Inoue et al.,for patients treated with SRS having an AVM volume $>10 \mathrm{cc}$, complete obliteration rate and hemorrhage rate was $36.4 \%$ and $35.7 \%$, respectively. In the study by Sirin et al. $.^{24}, 37$ patients were treated with prospective staged SRS and complete obliteration was observed in 7 of the 14 patients who completed 3 year follow-up. In our study, 3 patients were treated with prospective staged SRS and complete obliteration was achieved in 1 patient (33\%).

\section{CONCLUSION}

Linac-based SRS is a safe and effective treatment modality in the management of cerebral AVMs. Spetzler-Martin grade I-II and AVM size $<3 \mathrm{~cm}$ were found to be associated with increased oblite- 
ration rate $(\mathrm{p}=0.01)$. SRS offers an effective alternative to surgery for the treatment of particularly small AVMs inaccessible with surgery.

\section{REFERENCES}

1. Choi JH, Mohr JP. Brain arteriovenous malformations in adults. Lancet Neurol 17: 299-308, 2005.

2. Jalali R, Dutta D, Srinivas C, et al. Micromultileaf collimator-based stereotactic radiosurgery for selected arteriovenous malformations: Technique and preliminary experience. J Can Res Ther 5: 186-191, 2009.

3. Zabel A, Milker-Zabel S, Huber P, et al. Treatment outcome after linac-based radiosurgery in cerebral arteriovenous malformations: Retrospective analysis of factors affecting obliteration. Radiotherapy and Oncology 77: 105-110, 2005.

4. Zabel-Du Bois A, Milker-Zabel S, Huber P, et al. Pediatric cerebral arteriovenous malformations: the role of stereotactic linac-based radiosurgery. Int J Radiat Oncol Biol Phys 65: 1206-1211, 2006.

5. Friedman WA, Bova FJ, Mendenhall WM. Linear accelerator radiosurgery for arteriovenous malformations: The relationship of size to outcome. J Neurosurg 82: 180-189, 1995

6. Spetzler RF, Martin NA. A proposed grading system for arteriovenous malformation. J Neurosurg 65: 476483, 1986

7. Lunsford LD, Kondziolka D, Flickinger JC, et al. Stereotactic radiosurgery for arteriovenous malformations of the brain. J Neurosurg 75: 512-524, 1991.

8. Steiner L, Leksell L, Greitz T, et al. Stereotaxic radiosurgery for cerebral arteriovenous malformations. Report of a case. Acta Chir Scand 138: 459-464, 1972.

9. Steiner L, Leksell L, Forster DM, et al. Stereotactic radiosurgery in intracranial arterio-venous malformations. Acta Neurochir suppl 21: 195-209, 1974.

10. Schneider BF, Eberhard DA, Steiner LE. Histopathology of arteriovenous malformations after gamma knife radiosurgery. J Neurosurg 87: 352-357, 1997.

11. Gobin YP, Laurent A, Merienne L, et al. Treatment of brain arteriovenous malformations by embolization and radiosurgery. J Neurosurg 85: 19-28, 1996.

12. Hartmann A, Pile-Spellman J, Stapf C, et al. Risk of endovascular treatment of brain arteriovenous malformations. Stroke 33: 1816-1820, 2002.

13. Schlienger M, Atlan D, Lefkopoulos D, et al. LINAC radiosurgery for cerebral arteriovenous malformations: Results in 169 patients. Int J Radiat Oncol Biol Phys 46: 1135-1142, 2000.

14. Izawa M, Hayashi M, Chernov M, et al. Long-term complications after gamma knife surgery for arteriovenous malformations. J Neurosurg 102: 34-37, 2005.

15. Flickinger JC, Kondziolka D, Maitz AH, Lunsford LD. Analysis of neurological sequelae from radiosurgery of arteriovenous malformations: How location affects outcome. Int J Radiat Oncol Biol Phys 40: 273-278, 1998.

16. Engenhart R, Wowra B, Debus J, et al. The role of high-dose, single-fraction irradiation in small and large intracranial arteriovenous malformations. Int J Radiat Oncol Biol Phys 30: 521-529, 1994.

17. Miyawaki L, Dowd C, Wara W, et al. Five year results of linac radiosurgery for arteriovenous malformations: Outcome for large AVMs. Int J Radiat Oncol Biol Phys 44: 1089-1106, 1999.

18. Karlsson B, Lindquist C, Steiner L. The effect of gamma knife surgery on the risk of rupture prior to AVM obliteration. Minim Invasive Neurosurg 39: 21-27, 1996.

19. Friedman WA, Blatt DL, Bova FJ, et al. The risk of hemorrhage after radiosurgery for arteriovenous malformations. J Neurosurg 84: 912-919, 1996.

20. Pollock BE, Flickinger JC, Lunsford LD, et al. Hemorrhage risk after stereotactic radiosurgery of cerebral arteriovenous malformations. Neurosurgery 38: 652-661, 1996.

21. Liscák R, Vladyka V, Simonová G, et al. Arteriovenous malformations after Leksell gamma knife radiosurgery: rate of obliteration and complications. Neurosurgery 60: 1005-1016, 2007.

22. Pollock BE, Gorman DA, Coffey RJ. Patient outcomes after arteriovenous malformation radiosurgical management: Results based on a 5 to 14-year follow-up study. Neurosurgery 52: 1291-1297, 2003.

23. Inoue HK, Ohye C. Hemorrhage risks and obliteration rates of arteriovenous malformations after gamma knife radiosurgery. J Neurosurg 97: 474-476, 2002

24. Sirin S, Kondziolka D, Niranjan A, et al. Prospective staged volume radiosurgery for large arteriovenous malformations: Indications and outcomes in otherwise untreatable patients. Neurosurgery 58: 17-27, 2006.

\section{Correspondence \\ Dr. Ferrat DiNÇOĞLAN \\ Gülhane Askeri Tıp Akademisi \\ Radyasyon Onkolojisi Anabilim Dalı \\ Gn.Tevfik Saglam Cad. \\ Etlik, Keçiören \\ ANKARA / TURKEY}

Tel: $\quad$ (+90.312) 3044696

Fax: (+90.312) 3044680

E-mail: ferhatdincoglan@gmail.com 